\title{
OPTIMIZATION OF ANTISCORPION VENOM PRODUCTION
}

\author{
OZKAN O. (1), ADIGÜZEL S. (1), ATES C. (1), BOZYIGIT I. (1), FILAZI A. (2)
}

(1) Refik Saydam Hygiene Center, Ankara, Turkey; (2) Department of Pharmacology and Toxicology, Faculty of Veterinary Medicine, Ankara University, Ankara, Turkey.

ABSTRACT: The present study was carried out to produce highly efficient antivenom from a small number of telsons in a short time. Venom solution was prepared through maceration of telsons from Androctonus crassicauda (Olivier, 1807) collected in the Southeastern Anatolia Region, Turkey. Lethal dose 50\% (LD $\left.\mathrm{L}_{50}\right)$ of the venom solution injected into mice was $1 \mathrm{ml} / \mathrm{kg}$ (95\% confidence interval; 0.8-1.3), according to probit analysis. Different adjuvants (Freund's Complete Adjuvant, Freund's Incomplete Adjuvant, and $0.4 \%$ aluminium phosphate), at increasing doses and combined with venom, were subcutaneously injected into horses on days $0,14,21,28,35$, and 42 of the experiment. Antivenom was collected from the immunized horses on days 45 , 48, and 51 using the pepsin digestive method. The antivenom effective dose $50 \%$ $\left(E D_{50}\right)$ in mice was $0.5 \mathrm{ml}$ (95\% confidence interval; 0.40-0.58), according to probit analysis. It was concluded that $0.5 \mathrm{ml}$ antivenom neutralized a venom dose 35-fold higher than the venom $L_{50}$. Thus, highly potent antivenom could be produced from about 238 telsons in 51 days.

KEY WORDS: scorpion, antivenom, Androctonus crassicauda.

\section{CORRESPONDENCE TO:}

OZCAN OZKAN, Poison Research Center, Refik Saydam Hygiene Center, Ankara, Turkey. Phone: 00-90-312-433 70 01. Fax: 00-90-312-433 7000.

Email: ozcanozkan62@hotmail.com. 


\section{INTRODUCTION}

Scorpions are members of the order Scorpiones, class Arachnida, subgroup of Arthropoda (10). Within the 1,500 species defined so far, only 50 were stated to be dangerous to humans $(12,14)$. Lethal scorpions are mostly of the Buthidae family. Among these, the species belonging to Androctonus, Leiurus and Mesobuthus genera are considered the most significant in causing envenomations in Turkey (14). In cases of envenomation by scorpion stings, it is often recommended that patients be treated with species-specific antivenom (1). Scorpion antivenom treatment, initially introduced in 1909, is still the only method used for therapy $(6,16)$. In Turkey, scorpion antivenom has been produced in Refik Saydam Hygiene Center (RSHC) since $1942(17,18)$.

Also in Turkey, venom obtained through maceration of telsons from $A$. crassicauda scorpions is used as an antigen for antivenom production; this antigen is applied against other scorpion species too $(15,17,18)$. In such method, hyperimmunization of one horse requires venom from approximately 1,500-2,000 telsons in a period of 4-5 months (18). However, costs are rather high since both a great quantity of telsons and a long time are required to obtain antivenom. Therefore, this study was aimed at producing highly efficient antivenom in a shorter period of time using fewer telsons.

\section{MATERIALS AND METHODS}

\section{Animals}

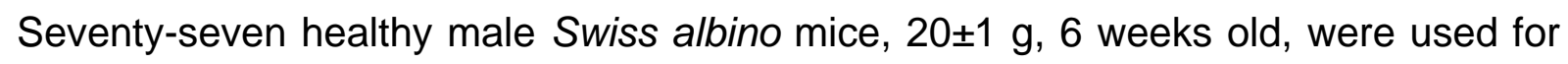
determination of the venom $\mathrm{LD}_{50}$, the antivenom $E D_{50}$, and the immune status of horses. Throughout the experiment, animals were kept in the experiment room under $22 \pm 2^{\circ} \mathrm{C}$ and $60 \pm 10 \%$ humidity. They were fed with commercial mouse pellets ad libitum.

Also, 5 local breed horses (300-400 kg), aged from 8 to 10 years, were used for the production of antivenom. During the hyperimmunization period, they were fed with barley and dried meadow grass. 


\section{Venom solution preparation}

Venom solution was prepared by the method of maceration $(3,4,7,19)$ using 1,350 telsons (approximately $20 \mathrm{~g}$ ) from $A$. crassicauda scorpions collected at the Southeastern Anatolia Region, Turkey. Telsons were ground to a fine powder and dissolved in physiologic saline solution (PSS - 0.9\% sodium chloride solution) to 150 $\mathrm{ml}$, resulting in a venom stock solution of $180 \mathrm{mg}$ telsons $/ \mathrm{ml}$.

\section{Determination of the Lethal Dose $50 \%\left(L D_{50}\right)$}

Different doses $(0.05,0.1,0.15,0.2,0.25$, and $0.3 \mathrm{ml})$ of the venom stock solution were separated in 3-ml tubes, which had their volumes completed with PSS, resulting in the following concentrations: $3,6,9,12,15$, and $15 \mathrm{mg} / \mathrm{ml}$, respectively.

To determine the venom LD $_{50}, 35$ mice were divided into 7 groups of 5 mice each. Then, $0.5 \mathrm{ml}$ of a different concentration of the above-mentioned venom solutions was subcutaneously injected into each group. Mice in groups 1, 2, 3, 4, 5, and 6 received $1.5,3,4.5,6,7.5$, and $9 \mathrm{mg}$ venom, respectively. Control group was treated with $0.5 \mathrm{ml}$ PSS, subcutaneously. Following treatment with venom solution, animals were monitored for 48 hours, and the number of dead animals was recorded at the end of the experiment. The dose that killed 50 percent animals (LD 50 ) was calculated using probit analysis $(8,9,20)$.

\section{Horse immunization}

The $L D_{50}$ values determined in mice were selected to induce primary immune responses in horses. Increasing venom doses were used to induce and maintain secondary immune responses. Adjuvants were used to enhance immune responses. On the first day, $180 \mathrm{mg}$ venom (macerated telsons), mixed half-and-half with Freund's Complete Adjuvant (FCA), was subcutaneously injected into horses for primary immunization, and on the $14^{\text {th }}$ day, $360 \mathrm{mg}$ venom, mixed half-and-half with Freund's Incomplete Adjuvant (FIA), was subcutaneously injected into horses for secondary immunization (v/v). To maintain immune responses, 720, 1,000, 1,000, and $1,500 \mathrm{mg}$ venom, mixed with $0.5 \mathrm{ml}$ of $0.4 \%$ aluminium phosphate $\left(\mathrm{AIPO}_{4}-\mathrm{v} / 0.5\right.$ $\mathrm{ml}$ ), were subcutaneously injected into horses on the $21^{\text {st }}, 28^{\text {th }}, 35^{\text {th }}$, and $42^{\text {nd }}$ days, respectively (Table 1 ). Thus, 4,760 $\mathrm{mg}$ telsons (approximately 238 pieces) were used for the hyperimmunization of one horse. 


\section{Immunization control}

Before each venom injection, we verified the immune status of horses to assess their antibody ( $\lg G)$ condition and to determine whether hyperimmunization could be performed.

On the $21^{\text {st }}, 28^{\text {th }}, 35^{\text {th }}$, and $42^{\text {nd }}$ days, $5 \mathrm{ml}$ blood samples were collected from the jugular vein of animals and stored in sterile bottles containing anticoagulants from the horses. After plasma separation, samples of each above-mentioned day were again stored in sterile bottles for determination of the $\mathrm{ED}_{50}$ (Figure 1). Neutralization was expressed as $\mathrm{ED}_{100}$. Immunization plan continued according to these potency results.

\section{Antivenom production}

On the $45^{\text {th }}, 48^{\text {th }}$, and $51^{\text {st }}$ days, $5 \mathrm{~L}$ blood samples were collected from the jugular vein of each animal for three times $(15 \mathrm{~L})$ and stored in containers with $10 \%$ sodium citrate. After plasma separation, $10 \mathrm{~L}$ antivenom was obtained from combined plasma (from $75 \mathrm{~L}$ blood in total) by the digestive method (15) and kept in the dark under $4^{\circ} \mathrm{C}$.

\section{Determination of the Effective Dose $50 \%\left(E D_{50}\right)$}

To assess the antivenom potency, venom stock solution, at a dose 35-fold higher than the $\mathrm{LD}_{50}$ for one mouse, was separated in 6 tubes $(0.7 \mathrm{ml}$ each). Each tube received $0.3,0.4,0.5,0.6,0.7$, and $0.8 \mathrm{ml}$, respectively, of the antivenom solution and had its volume completed to $3.5 \mathrm{ml}$ with PSS. These solutions of different concentrations were incubated at $37^{\circ} \mathrm{C}$ for one hour for antigen-antibody reaction. Then, $0.5 \mathrm{ml}$ of each solution was subcutaneously injected into a different group of mice (7 groups of 6 mice each); control group was subcutaneously injected with 0.5 $\mathrm{ml}$ venom solution (0.1 $\mathrm{ml}$ stock venom solution and $0.4 \mathrm{ml} P S S ; 5 \mathrm{LD}_{50}$ ).

After injection, animals were monitored for 48 hours. The number of living animals was recorded, and the $\mathrm{ED}_{50}$ was calculated according to probit analysis $(8,9,20)$.

\section{RESULTS}

The $\mathrm{LD}_{50}$ of venom prepared from macerated telsons was $1 \mathrm{ml} / \mathrm{kg}$ (95\% confidence interval; 0.8-1.3). Since $1 \mathrm{ml}$ venom contained $180 \mathrm{mg}$ telsons, LD $_{50}$ was also 
calculated as $180 \mathrm{mg} / \mathrm{kg}$. The venom and adjuvants doses administered to horses were determined according to the $\mathrm{LD}_{50}$ in mice (Table 1 ).

Depending on the adjuvant utilized, aseptic abscess developed in the neck of horses during the immunization period, requiring local dressing.

We verified the changes in the horse sera neutralizing capacity against the $\operatorname{LD}_{50}$ of $A$. crassicauda venom. Serum antibody concentration decreased (4, 3, 2, $1.5 \mathrm{ml})$ as venom concentration $\left(2,3,4,5 L_{50}\right)$ increased (Figure 1). With $5 L_{50}$ of venom, neutralization capacity of serum was $1.5 \mathrm{ml}\left(E D_{100}\right)$, whereas mice in the control group died.

Antivenom (10 L) was obtained from $75 \mathrm{~L}$ blood collected from horses after the administration of venom enriched with adjuvants. Its $E D_{50}$, determined according to the probit method, was $0.5 \mathrm{ml}$ (95\% confidence interval; 0.40-0.58), which was capable of neutralizing a venom dose 35-fold higher than the $\mathrm{LD}_{50}$ for one mouse $\left(L_{50}=3.6 \mathrm{mg}\right.$ telsons/mouse), being prepared in 51 days. Finally, only 238 telsons were needed for the immunization of one horse.

Table 1: Venom and adjuvant doses subcutaneously injected into each horse for hyperimmunization.

\begin{tabular}{ccc}
\hline Day & Venom (telsons) dose & Adjuvant dose \\
0 & $180 \mathrm{mg}$ & $1 \mathrm{ml} \mathrm{FCA}$ \\
14 & $360 \mathrm{mg}$ & $2 \mathrm{ml} \mathrm{FIA}$ \\
21 & $720 \mathrm{mg}$ & $0.5 \mathrm{ml} \mathrm{AlPO}_{4}$ \\
28 & $1,000 \mathrm{mg}$ & $0.5 \mathrm{ml} \mathrm{AlPO}_{4}$ \\
35 & $1,000 \mathrm{mg}$ & $0.5 \mathrm{ml} \mathrm{AlPO}_{4}$ \\
42 & $1,500 \mathrm{mg}$ & $0.5 \mathrm{ml} \mathrm{AlPO}_{4}$ \\
\hline
\end{tabular}

FCA: Freund's Complete Adjuvant

FIA: Freund's Incomplete Adjuvant AlPO 4 : 0.4\% Aluminium Phosphate 


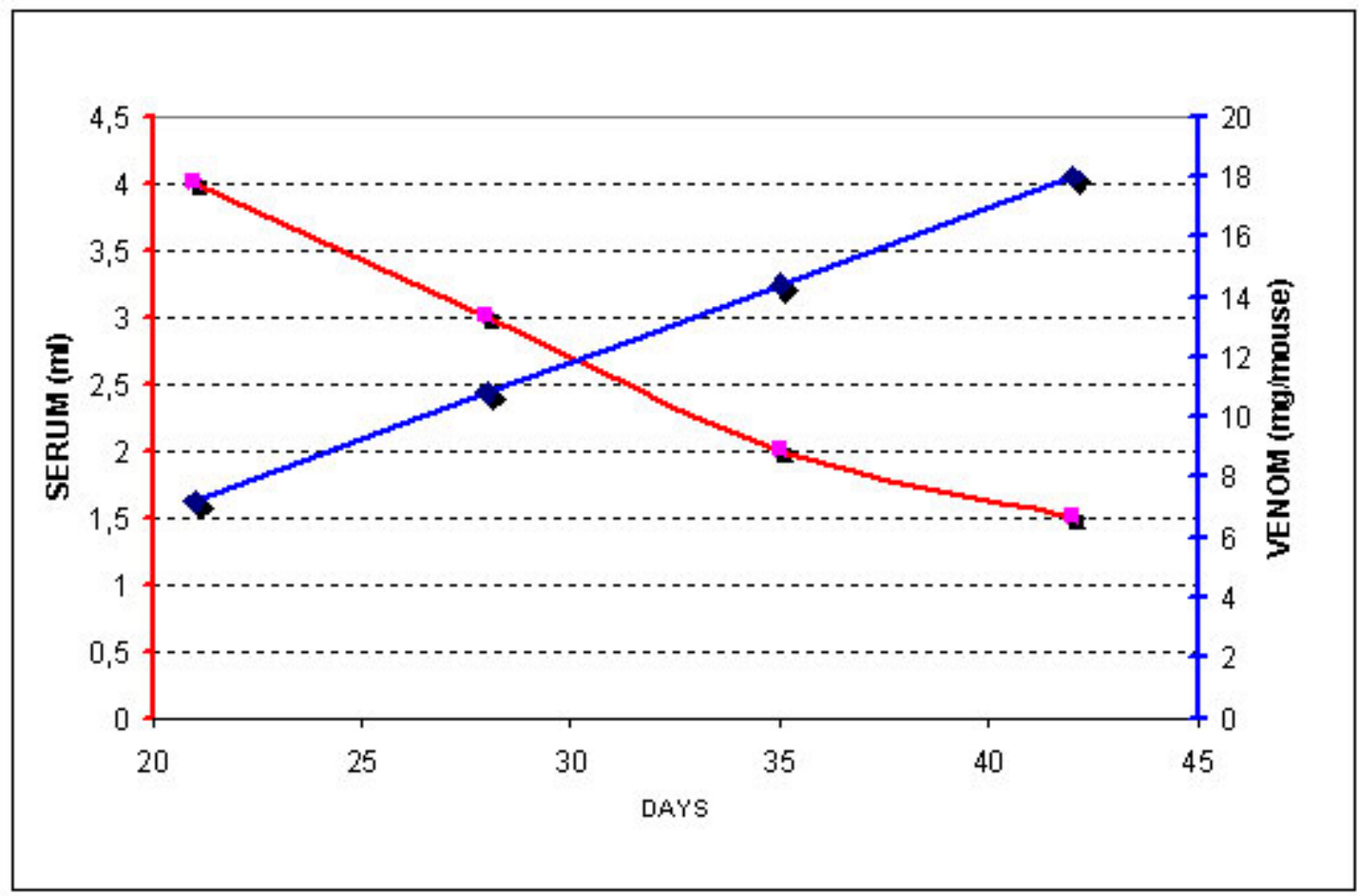

Figure 1: Changes of serum antibody concentration in horses immunized with Androctonus crassicauda venom for production of antivenom. Results are expressed as $E_{100}$ of serum $(\mathrm{ml})$ against 2, 3, 4, 5 LD 50 ( $\mathrm{mg}$ telson/mouse) in mice.

\section{DISCUSSION}

In this study, antivenom was produced in a short time with a small quantity of telsons. The $\mathrm{LD}_{50}$ obtained was $1 \mathrm{ml} / \mathrm{kg}$. It was calculated that $3.6 \mathrm{mg}$ telsons could $\mathrm{kill} \mathrm{a}$ mouse of approximately $20 \mathrm{~g}$. In other words, since 1 telson is about $20 \mathrm{mg}, 18 \%$ of it corresponds to the $\mathrm{LD}_{50}$ for one mouse. This conclusion was similar to that of Ozkan and Filazi, who used the same species of scorpions and stated that $16 \%$ of one telson corresponded to the LD 50 value for one mouse (13). However, Tulga, using the same scorpions species and methodology, reported that from $3.3 \%$ to $5 \%$ of one telson corresponded to the $\mathrm{LD}_{50}$ for one mouse (17).

Differences between scorpion venoms toxicities can be explained by different ways of collecting scorpions, changes in their physiologic status and feeding patterns. In addition, during capture and killing, scorpions could have used some venom to protect themselves, and factors such as telsons transporting conditions, drying method, storage and period of use could have influenced these differences too (13). 
Scorpion venoms are neurotoxins of fatal and paralytic activity but with poor antigenic properties since they are composed of simple proteins of low molecular weight (6, 21). Therefore, during hyperimmunization, every producer employs different techniques to increase these properties and consequently stimulate the immune system, ensuring the formation of an adequate number of antibodies (16). For this purpose, the Algerian Pasteur Institute produced antivenom by adding penicillin and streptomycin to saline solution, which was used as venom diluter; Tulga added 50\% of beef extract and $0.4 \%$ aluminium phosphate to venom solution (17). On the other hand, Mohamed et al. obtained antivenom by using purified picrate venom derived from telsons (11). In Turkey, production of scorpion antivenom by the Refik Saydam Hygiene Center (RSHC) utilizes beef extract and 4\% aluminium phosphate for the immunization of horses (4). In the Lister Institute of Preventive Medicine (UK), antivenom is obtained by adding $1 \%$ of broth with peptone and $0.4 \%$ aluminium phosphate to the venom solutions prepared from macerated telsons (3). Despite the fact that today aluminum hydroxide $(\mathrm{AIOH})$ or alginate is used as adjuvant in the production of antivenoms, it is suggested that using Freund's Complete Adjuvant (FCA) and Freund's Incomplete Adjuvant (FIA) would be more effective in increasing the immune response (16). In this study, FCA, FIA, and $0.4 \%$ aluminium phosphate were used as adjuvants in the production of antivenom.

To obtain venom from scorpions, methods such as maceration, manual techniques and electrical stimulation are applied. Maceration is one of the oldest and simplest methods based on the principle of keeping telsons of dead scorpions in physiologic saline solution $(6,7)$. To obtain an adequate amount of venom by this method, quite a few scorpions need to be killed. Venom obtained by this process is given to horses at increasing sublethal doses and antivenom is produced. The Algerian Pasteur Institute reported that one horse could be immunized against Androctonus australis venom by using 400-500 telsons (6). For the immunization of one horse, Tulga used 1,428 A. crassicauda macerated telsons, and this quantity may be increased from 1,500 to 2,000 to ensure an adequate hyperimmunization (18).

Today, in Turkey, venom obtained through maceration of telsons from A. crassicauda scorpions collected in the Southeastern Anatolia Region is used as antigen for the production of antivenom, and it is stated that the hyperimmunization of one horse requires from 1,500 to 2,000 telsons $(4,17,18)$. In the present study, antivenom 
used for hyperimmunization of one horse was produced through maceration of approximately $238 \mathrm{~A}$. crassicauda telsons.

The Algerian Pasteur Institute reported that to obtain an adequate immune response (produce antibodies), horses must be immunized for at least eight months (6). Tulga, on the other hand, produced antivenom in 100 days (17). In Turkey, according to the present antivenom production method used, 4-5 months are required for the hyperimmunization of one horse and consequently for the production of antivenom $(17,18)$. However, in this study, antivenom was produced in 51 days.

The European pharmacopoeia and the method mentioned in the technical reports of the World Health Organization $(8,20)$ were used during the determination of the potency of the antivenom produced in this study. We found out that $0.5 \mathrm{ml}$ antivenom, which corresponded to 35 LD $_{50}$ of the venom, protected $50 \%$ animals. Also, antivenom potency was studied based on the protocol used in the RSHC Biologic Control and Research Laboratory for $A$. crassicauda antivenom production $(4,5)$. It was observed that $0.2 \mathrm{ml}$ of antivenom prepared this way neutralized 2 Minimal Lethal Dose (2 MLD) of venom in rats (2).

According to the present results, potent antivenom can be produced in 51 days using a smaller number of telsons. Thus, with less animals collected, especially from the Southeastern Anatolia Region, the regional scorpion fauna can be protected.

\section{ACKNOWLEDGMENTS}

We wish to thank Karina Chamma for her valuable comments on this manuscript.

\section{REFERENCES}

1 ALEXANDER JO'D. Scorpion stings. In: ALEXANDER JO'D. Ed. Arthropods and human skin. Berlin: Springer-Verlag, 1984: 199-207.

2 ANDROCTONUS CRASSICAUDA ANTIVENOM POTENCY TEST PROCEDURE IN RATS. Biologic control and research laboratory (Laboratory textbook). 2004. 5.

3 ANTIVENOM PRODUCTION PROCESS. Lister Institute of Preventive Medicine. Federal Security Agency U.S. Public Health Service National Institute of Health (Textbook). 1948. 161. 
4 ANTIVENOM PRODUCTION PROTOCOL. Scorpion antivenom production protocol used Refik Saydam Hygiene Center. 1956. 46.

5 ANTIVENOM PROSPECTUS. Scorpion antivenom production prospectus used by Refik Saydam Hygiene Center of Turkish Republic Health Ministry. (Prospectus, using instruction). 2004. 2.

6 BALOZET L. Scorpionism in the Old World. In: BÜCHERL W., BUCKLEY E. Eds. Venomous animals and their venoms. New York: Academic Express, 1971: 349-71.

7 BÜCHERL W. Classification, biology and venom extraction of scorpion. In: BÜCHERL W., BUCKLEY E. Eds. Venomous animals and their venoms. New York: Academic Express, 1971: 317-47.

8 EUROPEAN PHARMACOPOEIA. 3. ed. Strasbourg: Council of Europe, 1997. 1712-3. (European Treaty Series, 50)

9 FINNEY DJ. Probit analysis. 3. ed. London: Cambridge University Press, 1971. $333 p$.

10 ISBISTER GK., GRAUDINS A., WHITE J., WARRELL D. Antivenom treatment in arachnidism. J. Toxicol. Clin. Toxicol., 2003, 41, 291-300.

11 MOHAMED AH., DARWISH MA., HANI-AYOBE M. Immunological studies on scorpion (B. quinquestriatus) antivenin. Toxicon, 1975, 13, 67-8.

12 MULLEN G., STOCKWELL SA. Scorpions (Scorpiones). In: MULLEN G., DURDEN L. Eds. Medical and veterinary entomology. Amsterdam: Academic Press, 2002: 411-23.

13 OZKAN O., FILAZI A. The determination of acute lethal dose-50 (LD $(L)$ levels of venom in mice, obtained by different methods from scorpions, Androctonus crassicauda (Oliver 1807). Acta Parasitol. Turcica, 2004, 28, 50-3.

14 OZKAN O., KARAER Z. The scorpions in Turkey. Turk. Hig. Deney. Biyol. Derg., 2003, 60, 55-62.

15 SEZGINMAN N., DEMIRTAS N. Purification and concentration of antitoxic sera. Turk. Hij. Tecr. Biyol. Derg., 1970, 30, 63-75.

16 THEAKSTON RD., WARRELL DA., GRIFFITHS E. Report of a WHO workshop on the standardization and control of antivenoms. Toxicon, 2003, 41, 541-57. 
17 TULGA T. Cross reactions between anti-scorpion (Buthus quinquestriatus) and anti-scorpion (Prionurus crassicauda) sera. Turk. Hij. Deney. Biyol. Derg., 1960, 20, 191-203.

18 TULGA T. Scorpions found in Turkey and paraspecific action of an antivenin produced with the venom of the species Androctonus crassicauda. Turk. Hij. Deney. Biyol. Derg., 1964, 24, 146-55.

19 WHITTEMORE Jr. FW., KEEGAN HL., BOROWITZ JL. Studies of scorpion antivenins. Bull. World Health Organ., 1961, 25, 185-8.

20 WORLD HEALTH ORGANIZATION. Requirement for snake antivenins. Geneva: World Health Organization, 1971. 21-44. (WHO Tech. Rep. Ser., 21)

21 ZLOTKIN E., MIRANDA F., ROCHAT H. Chemistry and pharmacology of Buthinae scorpion venoms. In: BETTINI S. Ed. Handbook of experimental pharmacology. Berlin: Springer-Verlag, 1978: 317-29. 